\title{
Influência de diferentes períodos de molhamento foliar na germinação de conídios de Pseudocercospora fuligena
}

\author{
Bernardo A. HALFELD-VIEIRA ${ }^{1}$, Kátia de Lima NECHET², Giovanni Ribeiro de SOUZA ${ }^{3}$
}

RESUMO

A mancha fuliginosa do tomateiro, causada por Pseudocercospora fuligena é uma doença incomum no Brasil, porém apresenta alto potencial de dano à cultura. O presente trabalho teve como objetivo estudar o efeito de diferentes períodos de molhamento foliar na germinação de conídios de $P$. fuligena. Conídios do patógeno foram coletados a partir de folíolos de tomateiro infectados e pincelados na face abaxial de folíolos sadios. Os tratamentos foram constituídos por folhas mantidas em câmara úmida durante $0,4,8,12,16,20$ e $24 \mathrm{~h}$, sendo avaliado o percentual de conídios germinados após $24 \mathrm{~h}$. Os resultados indicam que períodos superiores a $16 \mathrm{~h}$ de molhamento foliar nos folíolos proporcionam percentuais máximos de germinação dos conídios.

PALAVRAS-CHAVE: Epidemiologia, Mancha fuliginosa do tomateiro, Solanum lycopersicum, Lycopersicon esculentum, Cercospora fuligena.

\section{Influence of different leaf wetness periods in the conidial germination of Pseudocercospora fuligena}

\begin{abstract}
Tomato leaf mold caused by Pseudocercospora fuligena is an uncommon disease in Brazil; however, it presents high damage potential to the culture. The objective of this paper was to study the influence of different leaf wetness periods on conidial germination of $P$. fuligena. Conidia of the pathogen were collected from infected leaflets and inoculated on the abaxial side of healthy leaflets using a brush. Treatments were represented by leaves maintained in a humid chamber for $0,4,8,12,16,20$ e $24 \mathrm{~h}$ periods evaluating the percentage of germinated conidia after $24 \mathrm{~h}$. The experimental observations demonstrate that leaf wetness periods higher than $16 \mathrm{~h}$ proportionate the maximum percentage of conidial germination.
\end{abstract}

KEYWORDS: Epidemiology, Black leaf mold, Solanum lycopersicum, Lycopersicon esculentum, Cercospora fuligena.

\footnotetext{
${ }_{1}$ Pesquisador da Embrapa Roraima. Fitopatologia. Embrapa Roraima, BR 174, km 8, CP 133, 69301-970, Boa Vista-RR. e-mail:_halfeld@cpafrrembrapa.br

2 Pesquisador da Embrapa Roraima. Fitopatologia. E-mail: katia@cpafrr.embrapa.br

${ }^{3}$ Assistente A, Embrapa Roraima. E-mail: giovanni@cpafrr.embrapa.br
} 
A mancha fuliginosa (Pseudocercospora fuligena (Roldan) Deighton) do tomateiro (Solanum lycopersicum L.) é uma doença que ocorre em diversas regiôes tropicais e causa perdas significativas à cultura do tomateiro (Hartman \& Wang, 1992; Wang et al., 1995). Apesar de registrada no Brasil (Crous \& Braun, 2003), não se conhecem as áreas de incidência no País. Entretanto, em 2005 em Roraima danos consideráveis foram observados em plantas cultivadas em cultivo protegido (HalfeldVieira et al., 2006; Halfeld-Vieira et al., 2008).

$\mathrm{O}$ conhecimento dos fatores ambientais que influenciam as epidemias é importante na proposição de práticas para o manejo integrado da doença. Para a mancha fuliginosa do tomateiro, foram investigados a influência da umidade relativa do ar (UR) e da temperatura na germinação de conídios (Hartman et al., 1991). Estes autores verificaram que conídios de $P$. fuligena são capazes de germinar mesmo sem a presença de água líquida, quando mantidos continuamente nas UR de 100, 96,5, 93,5 e $91 \%$ por $24 \mathrm{~h}$, com valores percentuais máximos de germinação em UR superior a $96,5 \%$. Entretanto, não se tem informação sobre o efeito do período de permanência de água líquida na germinação de conídios, o que constituiu o objetivo deste trabalho.

Uma suspensão de conídios de $P$. fuligena, do isolado obtido por Halfeld-Vieira et al. (2006), foi preparada com esporos coletados manchas presentes em folíolos de plantas da cultivar Débora plus, 27 dias após a inoculação. Os folíolos foram colocados em béquer com água destilada esterilizada, em agitador magnético e a suspensão centrifugada a $7.000 \mathrm{~g}$ por 5 min, dispensando-se o sobrenadante.

O precipitado, contendo conídios obtidos após centrifugação, foi coletado e pincelado na face abaxial de folíolos sadios cultivar Débora plus. As folhas compostas foram mantidas com pecíolo imerso em água para manutenção de sua turgidez, permanecendo em câmara úmida em condiçôes de ambiente com temperatura variando entre 25 e $29^{\circ} \mathrm{C}$, faixa favorável para o desenvolvimento do patógeno (Hartman et al., 1991). Os períodos de permanência em câmara úmida foram de 0,4 , $8,12,16,20$ e $24 \mathrm{~h}$. A umidade relativa do ar no ambiente em que as amostras permaneceram variou entre 60 a $67 \%$.

Após as $24 \mathrm{~h}$ do início do experimento, foram iniciadas as avaliações, sendo depositados $120 \mu \mathrm{l}$ de água destilada na face abaxial dos folíolos pincelados com a suspensão de conídios, seguido de uma leve fricção e coleta desta alíquota em lâmina de microscopia. A suspensão obtida a partir dos folíolos foi avaliada em microscópio através da contagem de 100 conídios, determinando-se o percentual de conídios germinados.

Foram utilizadas três repetiçōes por tratamento, cada repetição constituída pela suspensão obtida de um folíolo. Para análise estatística, os dados de período de molhamento foliar e percentual de germinação de conídios foram utilizados para elaboração do gráfico e ajuste de modelo, calculando-se também os intervalos de confiança $(p \leq 0,05)$. Os programas utilizados foram o Microsoft Excel $^{\circledR} 2000$ (Microsoft Corporation) e SigmaPlot 2000 v. 6.00 (SPSS Inc.).

Os resultados indicam que o percentual de conídios germinados aumentou com o incremento do período de molhamento foliar. Os períodos acima de $16 \mathrm{~h}$ de molhamento foliar nos folíolos proporcionam percentuais máximos de germinação, pois os valores médios de germinação, referentes à 16,20 e $24 \mathrm{~h}$ de molhamento foliar, não diferiram estatisticamente (Figura 1).

Estes resultados indicam que o período em que os conídios de $P$. fuligena permanecem em ambiente com molhamento foliar exerce influência similar à UR a que estão submetidos continuamente por $24 \mathrm{~h}$ e que há exigência considerável em água no processo de germinação.

Os resultados obtidos podem auxiliar na estratégia de controle, em áreas de ocorrência da doença, procurando evitar

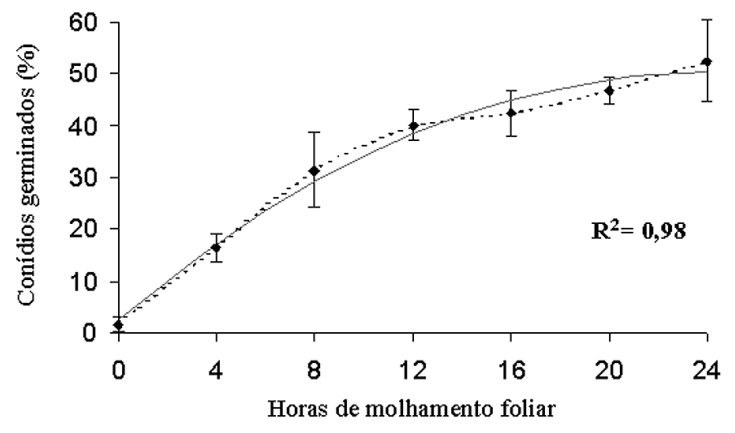

Figura 1 - Relação entre horas de molhamento foliar e percentual de conídios germinados. A linha pontilhada representa os valores médios observados e a linha contínua os valores ajustados, segundo o modelo quadrático $(y=-0,08$ $\left.x^{2}+3,98 x+2,38\right)$. As barras representam os intervalos de confiança.

as condiçôes que maximizam o potencial do patógeno no processo de infecção.

\section{BIBLIOGRAFIA CITADA}

Crous, P.; Braun, U. 2003. Mycosphaerella and its anamorphs: 1.names published in Cercospora and Passalora. CBS, Utrecht. $571 \mathrm{pp}$.

Halfeld-Vieira, B.A.; Nechet, K.L.; Barbosa, R.N.T. 2006. Pseudocercospora fuligena causing leaf mold of tomato in Roraima, Brazil. Fitopatologia Brasileira, 31(3): 320.

Halfeld-Vieira, B.A.; Nechet, K.L.; Souza, G.R. 2008. Reação de cultivares comerciais de tomateiro à mancha-fuliginosa. Tropical Plant Pathology, 33(5): 390-393.

Hartman, G.L.; Chen, S.C.; Wang, T.C. 1991. Cultural studies and pathogenicity of Pseudocercospora fuligena, the causal agent of black leaf mold of tomato. Plant Disease, 75(10): 1060-1063.

Hartman, G.L.; Wang, T.C. 1992. Black leaf mold development and its effect on tomato yield. Plant Disease, 76(5): 462-465.

Wang, T.C.; Hartman, G.L.; Hsieh, W.H.; Black, L.L. 1995. Reactions of solanaceous species to Pseudocercospora fuligena, the causal agent of tomato black leaf mold. Plant Disease, 79(7): 661-665,

Recebido em 26/10/2006

Aceito em 05/08/2008 